\title{
Effect of Structure and Strategy on Organizational Performance: Case Study of Remou Oil Nig. Ltd
}

\author{
Opusunju Michael Isaac ${ }^{1}$, Akyuz Murat ${ }^{2}$, Abdullahi Ibrahim Ahmed ${ }^{1}$ \\ ${ }^{1}$ Department of Business Administration, Nasarawa State University, Keffi, Nigeria \\ ${ }^{2}$ Department of Business Administration, Nile University of Nigeria, Abuja, Nigeria
}

Email address:

opusunjumike@gmail.con (O. M. Isaac), murat.akyuz@nileuniversity.edu.ng (A. Murat), ahmedangewa@gmail.com (A. I. Ahmed)

\section{To cite this article:}

Opusunju Michael Isaac, Akyuz Murat, Abdullahi Ibrahim Ahmed. Effect of Structure and Strategy on Organizational Performance: Case Study of Remou Oil Nig. Ltd. American Journal of Environmental and Resource Economics. Vol. 4, No. 4, 2019, pp. 139-143.

doi: 10.11648/j.ajere.20190404.14

Received: September 3, 2019; Accepted: September 29, 2019; Published: October 31, 2019

\begin{abstract}
The term strategy and structure is said to be a result of decision making by managers through analysing the firm's performance, market, segmenting the market, selecting the market, positioning themselves and using resources to implement the process. The paper seeks to examine the effects of strategy and structure on organizational performance using exploratory analysis of data of Remou Oil Nig. Ltd with an interview with management staff. The population is 50 and sample size is based on purposive sampling which are 10. It is discovered that strategy and structure are interdependent variables that firms must always consider when introducing new action or plan. It was also found that there is a positive relationship between structure and strategy that determine firm's performance in terms of net profit. Therefore, if a firm's structure change, strategies will also changes with changing demand and that structure affects strategy and the two variables determine the performance of a firm if properly matched and monitored. The recommendation is that: Remou Oil Nigeria Limited should use both structure and strategy as a source of increasing organizational performance in terms of profit since positive relationship exists between line structure and product differentiation strategy in Remou Oil Nig. Ltd. They should try to combine these variables together to enhance returns in terms of investment, equity, asset and net profit.
\end{abstract}

Keywords: Structure, Strategy, Organization and Performance

\section{Introduction}

The firm's structure is a way of helping an organization to achieve its stated goals and because of the fact that objectives are derived from the organization's overall strategy. It is logical that strategy and structure should be closely linked. If the firm focuses on providing certain services such as army services or police services and some time army protection in the community, its structure will be one that promotes standardized and efficient services. Also, a firm is attempting to employ a growth strategy by entering into global market; it will need a structure that is flexible, fluid and readily adaptive to the environment or that is functional, multi-divisional matrix and strategy business unit (federal structure).

Strategy and structure is said to be one of the most fundamental and significant part of an organization. Strategy and structure however come up by planning process which is during the process of management in the organization. Strategy is the direct result of decision-making and structure is the indirect result of decision making in an organization.

However, strategy and structure is said to be a result of decision making by managers through analysing the firm's performance, market, segmenting the market, selecting the market, positioning themselves and using resources to implement the process.

It is an important responsibility of management to design and implement the strategic organizational form best suited to the demands of its marketplace, customers, and business environment. Since firm competitors essentially have access to the same information and may have developed similar strategies, it is important to consider organizational design as one of the most powerful strategic weapons.

There are few studies conducted in the developing countries on the structure and strategy relationship especially in Nigeria and there is also few studies on the developed countries. This 
study shall contribute to the existing literature using the Nigeria perspective. And also there is an argument whether structure precedes strategy or strategy precedes structure. This study seeks to find out the problem of the age-old argument as to whether structure precedes strategy and the time that is considered recent when measured with the researches reviewed in this study.

This research attempts to fill the gap by investigating relationship between structure and strategy using Remou Oil Nig. Ltd with different variables like line structure and product differentiation strategy.

This research will help firms to have good strategy and structure relationship that will yield return on investment, return on capital employed, and return on asset, gross profit and net profit. It will also enable them to know whether structure precedes strategy or not and also be of help for academic research as well as other professional bodies.

The paper is to investigate the effect of strategy and structure on a firm's performance and specific aim or objectives of this paper is to contribute to the existing literature in this rather controversial area by introducing the effects of line structure and product different strategy on firm performance and to ascertain if there are interdependent, one precedes the other. Or both can be unified to establish organizational performance in terms of return on investment, return on capital employed and return on asset. The period of study is $2015-2016$ and the limitation of this study is the inability to consider other oil industry away from Remou Oil Nig. Ltd.

Focused on the above stated specified objectives of this study, the hypotheses are formulated in null form:

$\mathrm{HO}_{1}$ : There is no significant relationship between line structure and product differentiation strategy of a firm.

\section{Concept of Strategy}

The concept of strategy is a complex one [17]. Strategy as developing and communicating the firm's unique position, making trade-offs, and forging fit among activities [27]. Strategy is the pattern of objectives, purpose, goals and major policies and plans for achieving these goals stated in such a way so as to define what business the firm is in or is to be and the kind of company it is or is to be [27]. It is a systematic approach to a major and increasingly important responsibility of the general management position and relates the firm to its environment in a way that will assure its continued success and make it secure from surprises [6].

There are five main and interrelated definitions of strategy: Plan, Ploy, Pattern, Position and Perspective [21]. Strategy as a pattern of decisions in a company that determines and reveals its objectives, goals, plans for achieving those goals and defines the range of business the company is to pursue [3]. Strategy is a pattern of stream of decision focusing on a set of a resource allocation in an attempt to accomplish a position in an environment faced by the company [22].

Strategy is a practical plan for achieving an organization's mission and objectives [10]. Strategy is the determination of the basic long term goals and objectives of the firm and the adoption of courses of action and the allocation of resources necessary to carrying out these goals [8].

\subsection{Concept of Organizational Structure}

Organizational structure is the relatively stable and formed network of vertical and horizontal interconnections among jobs that constitute the organization [26]. Organizational structure is the system of dividing a firm's total work into units and allocating these units to people and departments. Structure defines the framework within which activities occur and when the strategies can be properly implemented [1]. He [1] classified structure into functional structure, multidivisional, matrix and strategy business unit structure.

An organizational structure defines how activities such as task allocation, coordination and supervision are directed towards the achievement of organizational aims [29]. It can also be considered as the viewing glass or perspective through which individuals see their organization and its environment. Thompson (2009), said that organizational structure is the internal differentiation and patterning of relationships. He also referred to structure as the means by which the organization sets limits and boundaries for efficient performance by its members, by delimiting responsibilities, control over resources, and other matters [29].

Organizational structure is an interrelated set of events which return to complete and renew a cycle of activities [14]. Organizational structure as a relatively and enduring allocation of work roles and administrative mechanisms that creates a pattern of interrelated work activities and allows the organization to conduct, coordinate, and control its activities [19]. Organizational structure as a technique in which the firm is differentiated and integrated [15].

Organizational structure is how job tasks are formally divided, grouped, and coordinated. To him, organization structure indicates an enduring configuration of tasks and activities [30]. In other words, organizational structure is a set of methods through which, the organization is divided into distinct tasks and then create a harmony between different duties. It is the formal system of task and reporting relationships that controls, coordinates, and motivates employees so that they cooperate to achieve an organization's goals [30]. Organizational structure as consisting of job positions, their relation- ships to each other and accountabilities for the process and sub-process deliverables [3].

\subsection{Concept of Organizational Performance}

Organizational performance is associated with quantity of output, quality of output, timeliness of output, presence or attendance on the job, efficiency of the work completed and effectiveness of work completed [18]. It is a standard to which someone does something such as a job or examination [23]. Organizational performance is the accomplishment of a given task measured against pre-set standards of accuracy, completeness, cost and speed [7]. 
Organizational performance is not defined by the action itself but by judgemental and evaluative processes [16, 20]. Moreover, only actions which can be scaled, i.e., measured are considered to constitute performance [9]. Performance is measured in terms of productivity, job satisfaction, turnover and absenteeism [9].

\subsection{Empirical Study}

The organizational approach to strategy maintains that strategies and structures are dependent variables being consequences of the organizational performance/success [10]. Also organizational structure and strategy are highly interdependent and must be complementary in many ways to ensure success [13]. Structure and strategy are interdependent and exercise an influence over each other [1].

A study was carried out to estimate the effect of structure on the performance mediating supply chain management and found that in stable environment, formal structure has a positive effect on the performance while in dynamic atmosphere negative effect is attained. They concluded that, there is a negative effect of structure on organizational effectiveness [34].

Previous study used 100 large US companies, after tracing the development of these companies, over 50 years and compiling extensive case histories of companies such as Dupont, general motors, standard oil of new Jensey and Sears. Chandler concluded that changes in corporate strategy precede and lead to changes in an organization's structure. He also found that firms usually begin with a single product or line. The simplicity of the strategy requires only a simple or loose form of structure (functional structure) to execute. Decision can be centralized in the hands of a single senior manager and complexity and formalization will be low. As organization grow, their strategies become more ambitious and elaborate, for example, an organization pursuing differentiation strategy must innovate to survive and cost leadership strategy must have access to cheap input unless they can maintain their uniqueness, they may lose their competitive advantage. An organization matches best with this strategy because it is flexible and maximizes adaptability $[8,31]$.

Strategy and structure need to be refined and adopted over time. To him, no matter how firm strategy and structure evolves, it however ensure that these two crucial elements always fully support each other, never hindering or impeding the effectiveness of the other. The author also believed that, a firm's initial strategy can often dictate the structure of the firm and the company's organizational structure must support its strategy and the firm's structure can aid or hinder employees in their roles. Strategies can also dictate the means by which structure are formed. Bureaucratic companies tend to generate a majority of strategic ideas at the top level management, companies with flatter structure on the other hand, often involve a range of employees in strategy sessions [10].

Researchers inverted Chandler's view, suggesting that strategy follows structure, for example, they point out that a multidivisional structure bases a firm towards a conglomerate strategy [12]. That is, the ownership structure affect the firm's strategic orientation [34] offered a balanced view suggesting or arguing that the relationship between structure and strategy is reciprocal. That is, structure follows strategy just as the left foot follows the right. Strategy control researchers found that structure can function as a control mechanism for critical decision making [34].

Strategies require different organizational designs to succeed, and added that one of the key ideas in organizational design is to align the organization with the strategy. To him, a surprising number of firms appear to have an organization that is poorly aligned with their strategy [24].

A similar study looked at 41 global firms and compared the actual organizational structure with what you expect, given the requirement of the firm's business environment. They found that only 17 of the 41 firms display strategy - structure match. for example, some firms would have a highly decentralized structure, despite being in a type of market that demand a high global standardization [25].

A study was conducted using local conditions affect firm strategy, for example, German companies tend to be hierarchical, Italian companies tend to be smaller and are run more like extended families. Such strategies and structures help to determine in which type of industry a firm excel. Firm desigsn an adequate organizational structure and draws up an effective strategy to figure out the best way and manner to enter new markets, remain competitive in existing ones and allocating resources to pursuing initiative along the way [27]. Business today has an attention deficit and the implication for business especially for issues of strategy and structure of a firm [27].

The importance of aligning structure with strategy in a firm and aligning everyone in the organization with your strategy is one of the most important things you can do beyond formulating and implementing great strategies. Alignment will make it much easier for management team to push the firm to the direction they intend; without good alignment with the strategy every bit of forward motion will be struggle.

Organizational design influences strategic direction while also existing to implement your strategy. To him, strategies often change over time, structure are usually much more static. Strategies are often decided in a board-room, in contrast structural changes can be implemented through the organization. Compounding the difficulty of this challenge is when firms had strategic or structural changes imposed upon them. When a firm's structure is not aligned to its strategy the effects on the firm is similar to that of an automobile not in alignment [11].

\subsection{Theories of Organisational Structure}

The theory of bureaucracy organizational structure supports this work. Bureaucratic organization was a logical, rational organization which was technically superior to all other forms. The key elements in the ideal bureaucratic type of organization were as follows: a well-defined hierarchy of legitimate authority, a division of labour based on functional specialization, clear statement of the rights and duties of 
personnel, rules and procedures in writing should exists with all decisions and situation as well as promotion based on technical competence [32]. Weber states that the way the organization is configured in terms of structure can be a source of strength or weakness for the organization. To him, organizational structure products are communication, response to changes, relationship and span of control [1]. Bureaucracy as creating a relationship between functional levels of an organizational hierarchy [2]. It is relationship between roles rather than between individuals [2].

Frederick Taylor (1856-1915) the father of scientific management movement sought strategies to effectively use in industrial organizations. He believed that if movement of staff at work place could be minimized, then productivity will be high in the organization. Taylor believed that, the establishment either high or low should clearly define tasks laid out before the organization. The carefully circumscribed task should require a full day's effort to complete. The staff in the organization should be given standardized conditions and appliances to accomplish the task with certainty. A high pay should be tied to successful completion. He also believed that failure should be penalized and that a task should be made so difficult as to be accomplished only by a first rate staff. This was the strategy used by Taylor to achieve efficiency in the organization [25].

\section{Methodology}

The method of analysis is exploratory. The researcher collected information by interviewing the management staff as well as non management staff of Remou Oil Nig. Ltd located in Abak Road, in Ikot Ekpene, Akwa Ibom State. The firm has a population of 50 employees and out of these 50 employees, 10 are the functional managers including marketing, production, store, accounting, transport, administrative managers. The junior staffs' in the organization is 40 and the method of selecting sampling size is purposive sampling. The sample size is 10 .

\section{Analysis and Discussion}

The information collected from the management staff of Remou Oil Nig. Ltd located in Abak Road, in Ikot Ekpene, Akwa Ibom State is that the firm initially operated on a single product line in 2015 but the firm structure changed to multiple product line in 2016 such as Tonimus oil, HD 90 oil, total 40 oil, premium oil, versa vista blended oil, Tonimus 90 with a strategy of product differentiation. They said when the company introduced a multiple line of business, the structure of the firm changed from single line structure to functional structure with a changing strategy to match with the structure. They said that a total profit of N3m was made in 2016 starting from the time they adopted functional strategy with matching strategy of production differentiation compared to the previous year 2015 of a profit of N1M.

Based on the analysis of the interviewed, it was found that, structure affect strategy, meaning that structure shape strategy of the firm. Due to the increase in profit of Remou Oil Nig. Ltd at $\mathrm{N} 1 \mathrm{~m}$ in 2015 to $\mathrm{N} 3 \mathrm{~m}$ in 2016 with the adoption of product differentiation strategy that matched with the functional structure, we can therefore ascertain that structure affect strategy and the two variables determine the success of a firm if properly matched and monitored.

Through the exploratory analysis of the Remou Oil Nig. Ltd and literature reviewed of many authors, it is discovered that strategy and structure are interdependent variables that firm must always consider when introducing new action or plan. Many authors accept that structure shape strategy and strategy also shape structure and that the two terms cannot be separated. The introduction of one structure will guarantee the introduction of another (strategy). Many authors such as [8, 12] that structure influence strategy and the influence determine organizational performance.

\section{Conclusion and Recommendation}

This study investigates the relationship between structure and strategy on organizational performance. Based on the selected sample size of 10 management staff and structure proxy like line structure as well as product differentiation as strategy proxy, there is a positive relationship between structure and strategy that determines the organizational performance of Remou Oil Nig. Ltd. The study concludes that, organizational structure is the major determinant of firm performance. Although, structure and strategy are interdependent in determining organizational performance in Remou Oil Nig. Ltd, this study was consistent with the study of Chandler (1962) and Hall (1980).

The study recommends that firms should use both structure and strategy as a source of increasing organizational performance in terms of profit since positive relationship exists between line structure and product differentiation in Remom Oil Nig. Ltd. They should try to combine this variables together to enhance returns in terms of investment, equity, asset and net profit.

\section{References}

[1] Abbab, J. E. (2013), corporate strategy: an introduction. Ocho house, keffi, Nigeria.

[2] Aderounmu W. O \& Ehiametakor E. T (1981), introduction to administration of schools in Nigeria, Ibadan, Evans Brothers (Nigeria Publishers) Limited.

[3] Andrews, K. (1971), the concept of corporate strategy. Richard D. Irwin, Inc. 3rd Edition.

[4] Andrews, K. R. (1998), the concept of corporate strategy. In H. Mintzberg, J. B. Quinn and S. Ghoshal; The strategy process. Prentice hall: London.

[5] Andrews, K. R. (1980), the concept of Corporate Strategy. Richard D. Irwing, Homewood, Ill, USA.

[6] Ansoff, I. H. (1988), the new corporate strategy. New York, John Wiley. 
[7] Business Dictionary website. 2010. http://www.Business Dictionary.com/definition/performance. Html (accessed 17 January 2015).

[8] Chandler, D. A. (1962). Strategy and structure, chapters in the history of the American industrial enterprise. Cambridge, MA: MT Press, USA.

[9] Campbell, J. P., McCloy, R. A., Oppler, S. H., \& Sager, C. E. (1993), a theory of performance, in E. Schmitt, W. C. Borman, \& Associates (Eds.), Personnel selection in organizations, San Francisco: Jossey-Bass.

[10] David, I. (2014). Strategy and structure of an organization. Demand media press.

[11] Daft, R. L. (1997), organizational theory and design. Cinicinnati, South Western.

[12] Hall, D. J. \& Saias, M. A. (1980), strategy follows structure: strategic management journal vol. 1, no 2 .

[13] Kpatel (2006), management and strategy essay notes. Study mode publisher.

[14] Katz, D. \& Kahn, R. (1978), The Social Psychology of organizations, New York, Wiley.

[15] Lawrence, A. \& Lorschj, A (1967). Organization and environment: Managing differentiation and integration. Boston: Division of Research. Graduate School of Business.

[16] Ilgen, D. R., \& Schneider, J. (1991). Performance measurement: A multi-discipline view, in C. L. Cooper \& I. T. Robertson (Eds.), International review of industrial and organizational psychology, Chichester: Wiley, Vol. 1Administration, Harvard University.

[17] Lenz, R. T. (1980).”Environmental Strategy, Organization Structure and Performance: Pattern in One Industry". Strategic Management Journal, 1 (3).

[18] Mathis, R. L. \& Jackson, J. H. (2009). Human resource management, Mason, OH, USA: South-Western Cengage Learning.

[19] Morgan J. G., (1966), image of organization. Thousand Ouks, Sage.
[20] Motowidlo, S. J., Borman, W. C., \& Schmit, M. J. (1997), a theory of individual differences in task and contextual performance. Human Performance 10.

[21] Mintzberg, H. (1978). Structuring of organization. Prentice Hall, USA.

[22] Mintzberg, H. (1973). "Strategy Making in Three Modes". California Management Review, (Winter), 16 (2).

[23] MacMillan Dictionary Website. Turnover definition. http://www.Macmillandictionary.com/dictionary/british/turnov er (accessed 3 October 2010).

[24] Nicolay, W. (2013). Why is to so difficult to align the structure with the strategy. Unpublished.

[25] Teresa, N. (2013). Managing human resources in the $21^{\text {st }}$ century and beyond: context and concept. Africa Christian Textbooks (ACTS)

[26] Noe, R. A., Hollenback, J. R. \& Wright P. M., (2000), human resources management. Boston: McGraw hill-Irvin.

[27] Porter, M. E., (1980), competitive strategy. Free press.

[28] Porter, M. E. (1996). What is strategy?. Harvard Business Review.

[29] Pugh, D. S., (1990). Organization theory. Harmond Sworth, Penguin.

[30] Sablybski, I. (2005), applying quantitative methods in organizations. Nova, Southeastern.

[31] Sree, R. R. (2010). How does strategy affect structure. Management articles repository of cite, power sponsor publisher.

[32] Schein, E. (1996), organization, culture and leadership, Wiley.

[33] Thompson, P. (2009), Organization: a critical Approach. Palgraue, Macmillan.

[34] Zhang et al (1994), mineralogical society of America, USA. 